Revista IBERC

v. 4 , n. 2 , p. $67-78$, maio/ago. 2021

www.responsabilidadecivil.org/revista-iberc

DOI: https://doi.org/10.37963/iberc.v3i2.132

\title{
O CONTRATO DE TRABALHO DESPORTIVO E A RESPONSABILIDADE CIVIL DO EMPREGADOR PELA CONTAMINAÇÃO POR CORONAVÍRUS NO CONTRATO ESPECIAL DE TRABALHO DESPORTIVO
}

\author{
THE SPORTS EMPLOYMENT CONTRACT AND THE EMPLOYER'S CIVIL LIABILITY FOR \\ CORONAVIRUS CONTAMINATION IN THE SPECIAL SPORTS \\ EMPLOYMENT CONTRACT
}

\author{
Priscilla Pereira Mateo ${ }^{i}$ \\ Pedro Paulo Teixeira Manus ii
}

\begin{abstract}
RESUMO: O presente trabalho busca expor uma visão global dos efeitos do contrato de trabalho desportivo. Apesar de lhe ser aplicável as regras do direito do trabalho, o referido contrato possui especificidades que o diferenciam sendo tratado, pois, como relação sui generis. Assim, pretende-se abordar os princípios gerais das relações de trabalho desportivo e as regras que lhes são inerentes. Após, expor-se-á os direitos e deveres dos atletas e das entidades desportivas, com especial ênfase às suas hipóteses de extinção. Estabelecida essa visão global dos contratos desportivos, o texto trará reflexão a respeito da multiplicidade dos problemas que a COVID-19 faz surgir em sede de responsabilidade civil no contrato especial de trabalho desportivo.
\end{abstract}

Palavras-chave: contrato especial de trabalho desportivo; características próprias; extinção e suspensão do contrato especial de trabalho; responsabilidade civil; coronavírus.

\begin{abstract}
The present work seeks to expose a global view of the sports employment contract's effects. Although the labor law rules apply to it, the contract has specificities that set it apart, being it treated as a sui generis relationship. Thus, it is intended to address the general principles of sports work relations and the rules that are inherent to them. Afterwards, the rights and duties of athletes and sports entities will be exposed, with special emphasis on their extinction. Once this global vision of sports contracts is established, the text will reflect on the multiplicity of problems that COVID-19 raises in terms of civil liability in the special sports employment contract.
\end{abstract}

Keywords: special sports employment contract; own characteristics; extinction and suspension of the special employment contract; civil responsibility; coronavirus.

SUMÁRIO: 1. Introdução. 2. Noções gerais do Direito Desportivo. 3. A relação de trabalho desportivo. 3.1. Modos

' Possui graduação em Direito pela Pontifícia Universidade Católica de São Paulo (2010). Atuou como professora tutora no Damásio Educacional, em curso preparatório para o Exame da Ordem dos Advogados do Brasil (OAB). Foi professora assistente na disciplina de Prática Trabalhista na Faculdade Damásio. Advogada, atua na área do Direito do Trabalho tendo carreira nos escritórios Mannrich, Senra e Vasconcelos Advogados e Queiroz e Lautenschläger Advogados. Tem experiência na área de Direito do Trabalho, atuando principalmente no consultivo, contencioso e auditoria. É membro da Associação dos Advogados de São Paulo. Participou do V Congresso Internacional de Direito do Trabalho, denominado "Responsabilidade Socioambiental: Novos desafios do Direito do Trabalho", promovido pela Academia Brasileira de Direito do Trabalho e a International Labour and Employment Relations Association. E-mail: advppriscilla@gmail.com / ORCID https://orcid.org/0000-0002-4323-1015

ii Possui Graduação em Direito pela Pontifícia Universidade Católica de São Paulo (1973), Mestrado em Direito do Trabalho pela Universidade de São Paulo (1983) e Doutorado em Direito do Trabalho pela Pontifícia Universidade Católica de São Paulo (1995). Ministro Aposentado do Tribunal Superior Trabalho - TST (2007-2013). Atualmente, é Vice-Reitor da Pontifícia Universidade Católica de São Paulo. Professor Titular de Direito do Trabalho da Pontifícia Universidade Católica de São Paulo, Professor Convidado da Escola Superior de Advocacia da OAB, Secção de São Paulo. Foi Diretor da Faculdade de Direito da Pontifícia Universidade Católica de São Paulo (20172020). Advogado. E-mail: gmppm@tst.jus.br / ORCID https://orcid.org/0000-0003-3016-886X 
de extinção e suspensão do contrato de trabalho desportivo. 4. Responsabilidade civil do empregador por contaminação por coronavírus no Contrato Especial de Trabalho Desportivo. 5. Conclusão. 6. Referências.

\section{INTRODUÇÃO}

O direito do trabalho visa regulamentar as relações entre empregados e empregadores, contudo, não se desconhece que determinadas relações possuem características próprias, diferenciando-as das demais relações laborais. É o caso do Contrato Especial de Trabalho Desportivo. Desta feita, o presente trabalho tem por finalidade abordar essa espécie de relação empregatícia, apontando eventuais diferenças em relação aos demais tipos de contratos de trabalho. Busca-se, com isso, apresentar uma visão geral dos efeitos do contrato de trabalho desportivo. Diante da crise na saúde e do cenário único no qual todos foram emergidos, analisar-se-á a responsabilidade civil do empregador pela contaminação por Coronavírus no Contrato Especial de Trabalho Desportivo.

Para tanto, inicia-se o estudo pelos princípios e regras gerais das relações de trabalho desportivo. Destaca-se a relação do princípio da autonomia, com os princípios do direito social e educação. Expor-se-á, igualmente, com fulcro na Lei n $9.615 / 98$, os direitos e deveres previstos para os atletas e as entidades desportivas, reciprocamente considerados, em razão da dicotomia entre prestação de serviço e relação laboral.

Após, serão tratadas as hipóteses de extinção da relação contratual e a eventual incidência de multa compensatória, cuja responsabilidade pelo pagamento, igualmente, é objeto de controvérsia. Abordados os aspectos gerais da relação esportiva, realizar-se-á reflexão a respeito da responsabilidade civil do empregador em caso de contaminação por Coronavírus.

\section{NOÇÕES GERAIS DO DIREITO DESPORTIVO}

O direito ao desporto, por ser uma manifestação da vida social, que muito concorre para o desenvolvimento psíquico, para o adestramento do corpo e para a valorização das aptidões humanas, está protegido pelo ordenamento jurídico contra quaisquer violações. Todo cidadão, especialmente os atletas, têm direito ao desporto, ou seja, de exercer atividade desportiva.

O desporto é imprescindível à educação, permitindo maior integração dos brasileiros e de toda a humanidade. O direito desportivo está consagrado nos artigos $5^{\circ}, \mathrm{XXVIII}$, a ( $2^{\mathrm{a}}$ parte), e 217 , I a IV, $\S \S 1^{\circ}, 2^{\circ}$ e $3^{\circ}{ }^{1}$ da Constituição Federal, está ligado ao Direito Civil, no que atina às noções de capacidade, de personalidade jurídica, de contrato e de responsabilidade civil e ao Direito Comercial, principalmente, na contratação de atletas profissionais, que evidencia grande especulação.

\footnotetext{
1 "Art. 217. É dever do Estado fomentar práticas desportivas formais e não-formais, como direito de cada um, observados: I - a autonomia das entidades desportivas dirigentes e associações, quanto a sua organização e funcionamento; II - a destinação de recursos públicos para a promoção prioritária do desporto educacional e, em casos específicos, para a do desporto de alto rendimento; III - o tratamento diferenciado para o desporto profissional e o não- profissional; IV - a proteção e o incentivo às manifestações desportivas de criação nacional. $\S 1^{\circ} \mathrm{O}$ Poder Judiciário só admitirá ações relativas à disciplina e às competições desportivas após esgotarem-se as instâncias da justiça desportiva, regulada em lei. $\S 2^{\circ} \mathrm{A}$ justiça desportiva terá o prazo máximo de sessenta dias, contados da instauração do processo, para proferir decisão final. § $3^{\circ} \mathrm{O}$ Poder Público incentivará o lazer, como forma de promoção social."
} 
A legislação desportiva brasileira nasce com a Comissão Nacional de Desportos, criada pelo Decreto-Lei 1.056/1939. Em 1941, durante a Segunda Guerra Mundial, é editado o Decreto-Lei $n^{\circ}$ $3.199 / 41$.

É relacionado ao Direito Trabalho por se concretizar através da celebração de Contrato Especial de Trabalho Desportivo. O desporto brasileiro abrange a prática desportiva formal, que é regulada por normas nacionais e internacionais e pelas regras de prática desportiva de cada modalidade, aceitas pelas respectivas entidades nacionais de administração do desporto (Decreto $\mathrm{n}^{\circ}$ $7.984 / 2013$, artigo $\left.2^{\circ}, \S^{\circ}\right)$ e, a prática desportiva não formal, que é caracterizada pela liberdade lúdica de seus praticantes (artigo $1^{\circ}$, $\S \S 1^{\circ}$ e $2^{\circ}$, da Lei $n^{\circ} 9.615 / 98$ e artigo $2^{\circ}$, $\S 2^{\circ}$, do Decreto $n^{\circ} 7.984 / 2013$ ).

O esporte é a forma de lazer mais importante de uma sociedade. Nesse sentido, todos podem se exercitar sem regras, contudo, somente com regras é possível vencer ou disputar determinado jogo. Portanto, as regras são inerentes ao desporto.

O Direito Desportivo é um "universo de regras e leis" aptos a viabilizar disputas no mundo do esporte. O desporto constitui uma atividade de lazer cuja dominante é o esforço físico, participando simultaneamente do jogo e do trabalho, praticada de forma competitiva, comportando regras e instituições específicas; e suscetível de se transformar em atividade profissional.

Dessa forma, a organização desportiva de um País é fundamental, sendo considerada patrimônio cultural de elevado interesse social.

O desporto tem como base os princípios: a. da soberania; b. da autonomia; c. da democratização; d. da liberdade, expresso pela livre prática do desporto, de acordo com a capacidade e interesse de cada um, associando-se ou não a entidade do setor; e. do direito social; $f$. da diferenciação, consubstanciado no tratamento especifico dado ao atleta profissional e não profissional; g. da identidade nacional, refletindo a proteção e incentivo às manifestações desportivas de criação nacional; h. da educação, voltado para o desenvolvimento integral do homem como ser da descentralização autônomo e participante, e fomentado por meio da prioridade dos recursos públicos ao desporto nacional; i. princípio da qualidade, assegurado pela valorização dos resultados desportivos, educativos e dos relacionados à cidadania e ao desenvolvimento físico e moral; j. da descentralização, consubstanciado na organização e funcionamento harmônicos de sistemas desportivos diferenciados e autônomos para os níveis federal, estadual, distrital e municipal; k. da segurança; e, I. da eficiência, conforme se extrai do art. $2^{\circ}$ da Lei $n^{\circ} 9.615 / 98^{2}$.

O desporto brasileiro abrange a prática desportiva formal, que é regulada por normas nacionais e internacionais e pelas regras de prática desportiva de cada modalidade; e, a prática desportiva não formal, que é caracterizada pela liberdade lúdica de seus praticantes

A exploração e a gestão do desporto profissional deverão observar, além daqueles inscritos no artigo $2^{\circ}$ da Lei 9.615/1998, os princípios da transparência financeira e administrativa, moralidade na gestão desportiva, responsabilidade social de seus dirigentes, tratamento diferenciado em relação ao desporto não profissional e da participação na organização desportiva do País.

A Lei 9.615/98, com a alteração da Lei $n^{\circ} 10.672 / 2003$, traça algumas normas atinentes ao

\footnotetext{
2 DINIZ, Maria Helena. Tratado teórico e prático dos contratos. 7. ed. São Paulo: Saraiva, 2013, v. 5, passim.
} 
desporto não profissional. $\mathrm{O}$ atleta não profissional em formação, maior de quatorze e menor de vinte anos de idade, poderá receber auxílio financeiro da entidade de prática desportiva formadora, sob a forma de bolsa aprendizagem livremente pactuada mediante contrato formal, sem que seja gerado vínculo empregatício entre as partes (artigo $29, \S^{\circ}$ ).

A entidade de prática desportiva que forneça aos atletas programas de treinamento nas categorias de base e complementação educacional, poderão ser consideradas "formadoras de atleta".

No campo do futebol, por exemplo, a Confederação Brasileira de Futebol, estabeleceu por meio da RDP ${ }^{\circ}$ 01/2012 normas, procedimentos e diretrizes para emissão do Certificado de Clube Formador (CCF) pela CBF. No instrumento, constam como requisitos, por exemplo, fornecer alimentação para os atletas (refeições balanceadas com acompanhamento de nutricionista), meios para que o atleta possa viajar para sua cidade de origem, todo tipo de assistência médica e psicológica, assegurar transporte para treinos e jogos, comprovar o pagamento mensal de auxílio financeiro para o atleta em formação, sob a forma de bolsa de aprendizagem, sem que constitua vínculo empregatício, manter alojamento e uniformes. Veja-se que os requisitos elencados na Resolução devem ser devidamente comprovados para que se obtenha a certificação de "formador".

Por certo que, conforme se demonstrará adiante, o Clube Formador, diante do cenário imposto pela COVID-19, também, deverá zelar pela saúde desses atletas em formação sob pena de responsabilidade civil por eventuais danos pessoais e patrimoniais.

\section{A RELAÇÃO DE TRABALHO DESPORTIVA}

A relação contratual entre jogador e associação desportiva tem natureza especial ou sui generis, regida pela Lei 9.615/98 (regulamentada pelo Dec. n. 7.984/2013 e alterada pelas Leis 9.981/2000 e 10.672/2003), artigos $28, \S 1^{\circ}$, a 38 (com a redação da Lei $n^{\circ} 12.395 / 2011$ ), especificamente. Veja-se que o grande número de competições obrigatórias cria direitos e deveres recíprocos, nem sempre estabelecidos contratualmente.

O contrato entre jogador e entidade desportiva é considerado como pertencente à seara trabalhista, por pressupor subordinação, dependência econômica, por haver remuneração pactuada contratualmente e estabilidade do jogador. Devido à peculiaridade de sua profissão e à finalidade de sua atividade, o empregado goza de direito a uma indenização adicional àquela resguardada aos empregados tradicionais na hipótese de ser despedido injustificadamente.

O contrato de prestação de serviços profissionais entre atleta e entidade desportiva é o acordo de vontades em que uma das partes, sob subordinação se obriga para com a outra a exercer temporariamente sua atividade esportiva, mediante remuneração. É vedada sua celebração por meio de terceiros.

É um contrato: a) bilateral, por gerar obrigações para ambos os contratantes; b) oneroso, visto que acarreta vantagens para os contraentes, mediante contraprestações recíprocas; c) temporal, pois deve haver um prazo para a sua vigência, o qual não poderá ser inferior a três meses, nem superior a cinco anos. É o que se depreende do artigo 29 da Lei 9.615/98: 
Art. 29. A entidade de prática desportiva formadora do atleta terá o direito de assinar com ele, a partir de 16 (dezesseis) anos de idade, o primeiro contrato especial de trabalho desportivo, cujo prazo não poderá ser superior a 5 (cinco) anos.

O vínculo de emprego nascerá com a celebração do contrato de trabalho que é um contrato especial de trabalho. Nesse contrato, obrigatoriamente, existirá prazo determinado e cláusulas obrigatórias. O vínculo desportivo será sempre acessório ao vínculo de emprego pois surge somente com a averbação do contrato de trabalho na respectiva entidade de administração do desporto, conforme previsão expressa:

(...) $\S 5^{\circ} \mathrm{O}$ vínculo desportivo do atleta com a entidade de prática desportiva contratante constitui-se com o registro do contrato especial de trabalho desportivo na entidade de administração do desporto, tendo natureza acessória ao respectivo vínculo empregatício, dissolvendo-se, para todos os efeitos legais:

I - com o término da vigência do contrato ou o seu distrato;

II - com o pagamento da cláusula indenizatória desportiva ou da cláusula compensatória desportiva;

III - com a rescisão decorrente do inadimplemento salarial, de responsabilidade da entidade de prática desportiva empregadora, nos termos desta Lei;

IV - com a rescisão indireta, nas demais hipóteses previstas na legislação trabalhista;

$\mathrm{e}$

$\mathrm{V}$ - com a dispensa imotivada do atleta.

Os meios terminativos do contrato serão tratados adiante, sendo que por ora, cumpre esclarecer que a entidade de administração do desporto será a Federação correspondente ao clube empregador do atleta, sendo o requisito inicial para o registro desportivo o contrato de trabalho desportivo válido, isto é, com o preenchimento das exigências básicas quanto ao contrato para registro (requisitos subjetivos, objetivos e formais), bem como apresentação da documentação necessária.

Interessante observar que de acordo com a previsão constante na revogada Lei $n^{\circ} 6.354 / 76$, o vínculo empregatício era acessório do vínculo desportivo, que era o principal.

Com relação aos deveres do jogador empregado ou do atleta, tem-se o de concentrar-se, mantendo-se isolado até o momento da competição (ex.: para o futebolista o prazo não poderá ser superior a 3 dias consecutivos por semana), o dever de não se recusar a tomar parte das sessões preparatórias com dedicação e em competições dentro ou fora do país, dever de se submeter às sanções previstas nos códigos disciplinares. O jogador empregado deverá devolver luvas recebidas e o adiantamento de salário na proporção do restante prazo contratual se foi o culpado pela rescisão do contrato, cumprir às determinações do CDDB (Conselho de Desenvolvimento do Desporto Brasileiro) e preservar suas condições físicas, submetendo-se aos exames médicos e tratamento clínicos necessários à prática do esporte.

No caso do jogador empregado estrangeiro, não poderá participar como integrante de equipe nacional em campeonatos oficiais, quando estiver com visto temporário (Art. 46. Ao estrangeiro atleta profissional de modalidade desportiva, referido no inciso $V$ do art. 13 da Lei $n^{\circ} 6.815$, de 19 de agosto de 1980, poderá ser concedido visto, observadas as exigências da legislação específica, por prazo não excedente a 5 (cinco) anos e correspondente à duração fixada no respectivo contrato especial de trabalho desportivo, permitida uma única renovação.).

Por outro lado, o atleta profissional faz jus os direitos trabalhistas constitucionalmente 
assegurados, às "luvas" pagas ao atleta quando sua contratação tem natureza salarial e integram o salário, compondo a remuneração e incidindo no cálculo das verbas salariais, aos benefícios previdenciários, como por exemplo aposentadoria, aos recursos de assistência social e educacional e, também, auxílio financeiro, quando entre 14 e 20 anos, de entidade formadora, entre outros.

Outro direito do atleta profissional é o direito de arena, ou seja, de usufruir, se participante de espetáculo desportivo, de parte do quantum recebido pela associação desportiva não só para autorizar a fixação, transmissão ou retransmissão por quaisquer meios, obedecidas as convenções e contratos firmados, como também para comercializar imagens. É um direito que pertence às entidades de prática desportiva, consistente na prerrogativa exclusiva de negociar, autorizar ou proibir a captação, a fixação, a emissão, a transmissão, retransmissão ou reprodução de imagens, por qualquer meio, de espetáculo desportivo de que participem.

No âmbito trabalhista existia verdadeira cizânia sobre o fato do direito de arena integrar ou não a remuneração dos atletas profissionais. Existiam entendimentos para ambos os lados nos tribunais superiores trabalhistas, contudo, após o ano de 2011, em que foi editada a Lei 12.395/2011, que alterou a redação do artigo $42, \S 1^{\circ}$ da Lei $9.615 / 98$, restou claro que o valor não seria mais repassado pelo clube, mas pelo sindicato, afastando a natureza salarial. Veja-se que o direito de arena tem natureza civil, logo é uma espécie do direito de imagem, na medida em que o fato gerador é comum. Portanto, se o direito de imagem possui natureza civil, a mesma sorte deve seguir o direito de arena que é uma espécie de direito de imagem.

Por suas características próprias e por ser contrato especial, aproxima-se de um contrato de prestação de serviços profissionais a entidades desportivas, sobrevivendo nesta configuração jurídica, não obstante possam ser-lhes aplicadas analogicamente normas de direito do trabalho e de seguridade social. É contrato típico e especifico do direito do desporto.

Vale frisar que são nulas de pleno direito as cláusulas de contratos firmados entre as entidades de prática desportiva e terceiros, ou entre este e à atletas, que possam intervir ou influenciar nas transferências de atletas ou, ainda, que interfiram no desempenho do atleta ou da entidade de prática desportiva, exceto quando objeto de acordo ou convenção coletiva de trabalho.

No que diz respeito a processualística dos litígios desportivos, tem-se no artigo 217 da Constituição Federal, que "§ $1^{\circ} \mathrm{O}$ Poder Judiciário só admitirá ações relativas à disciplina e às competições desportivas após esgotarem-se as instâncias da justiça desportiva, regulada em lei.".

Portanto, eventual litigio surgido entre jogador e associação desportiva terá início por meio de petição inicial assinada pelo atleta e seu responsável, dirigida em duas vias ao Presidente do Tribunal de Justiça Desportiva.

\subsection{MODOS DE EXTINÇÃO E SUSPENSÃO DO CONTRATO DE TRABALHO DESPORTIVO}

Os modos terminativos do contrato desportivo estão tratados no artigo $28, \S 5^{\circ}$ da $9.615 / 98$, sendo eles: 1) com o término da vigência do contrato ou o seu distrato, sem renovação; 2) com o pagamento da cláusula indenizatória desportiva ou da cláusula compensatória desportiva; 3) com a dissolução legal da entidade desportiva; 4) com a rescisão do contrato e eliminação do futebol nacional 
por motivo de ato de improbidade, grave incontinência, mau comportamento, entre outras condutas, 5) com a morte do jogador e, 6) com o distrato, isto é, rescisão feita de comum acordo, exarada por meio de documento escrito e inscrita no Cartório de Registro de Documentos.

As cláusulas indenizatórias: desportiva e compensatória desportiva merecem destaque. Tratam-se de cláusulas obrigatórias no contrato desportivo. A contratação do seguro para o atleta profissional, também, é uma obrigação decorrente da legislação desportiva.

A cláusula indenizatória desportiva, devida exclusivamente à entidade de prática desportiva à qual está vinculado o atleta, será acionada nas seguintes hipóteses: a) transferência do atleta para outra entidade, nacional ou estrangeira, durante a vigência do contrato especial de trabalho desportivo; ou b) por ocasião do retorno do atleta às atividades profissionais em outra entidade de prática desportiva, no prazo de até 30 (trinta) meses. Mas, pelo artigo 40, §2 ${ }^{\circ}$ da Lei 12.395/2011:

O valor da cláusula indenizatória desportiva internacional originalmente pactuada entre o atleta e a entidade de prática desportiva cedente, independentemente do pagamento da cláusula indenizatória desportiva nacional, será devido a esta pela entidade de prática desportiva cessionária caso está venha a concretizar transferência internacional do mesmo atleta, em prazo inferior a 3 (três) meses, caracterizando o conluio com a entidade de prática desportiva estrangeira.

O valor da cláusula compensatória desportiva será livremente pactuado entre as partes e formalizado no contrato especial de trabalho desportivo, observando-se, como limite máximo, 400 vezes o valor do salário mensal no momento da rescisão e, como limite mínimo, o valor total de salários mensais a que teria direito o atleta até o término do referido contrato (artigo $28, \S \S 1^{\circ}$ a $3^{\circ}$, com a redação da Lei $n^{\circ}$ 12.395/2011), para transações nacionais.

Trata-se de disposição que permite ao atleta dispor de sua carreira, isto é, usar de sua faculdade para mudar de empregador. Ao passo que garante ao Clube, titular dos direitos daquele atleta, não seja prejudicado nos investimentos realizados. Portanto, o valor envolvido nessa cláusula terá essa dupla função: liberatória e indenizatória.

A cláusula compensatória, devida exclusivamente ao atleta, será acionada no caso de rescisão decorrente do inadimplemento salarial, de responsabilidade da entidade de prática desportiva empregadora, nos termos desta Lei e com a dispensa imotivada do atleta.

As formas de suspensão do contrato de atleta profissional, estão previstas no artigo 28 , da Lei 9.615/98:

(...) $\S 7^{\circ} \mathrm{A}$ entidade de prática desportiva poderá suspender o contrato especial de trabalho desportivo do atleta profissional, ficando dispensada do pagamento da remuneração nesse período, quando o atleta for impedido de atuar, por prazo ininterrupto superior a 90 (noventa) dias, em decorrência de ato ou evento de sua exclusiva responsabilidade, desvinculado da atividade profissional, conforme previsto no referido contrato.

$\S 8^{\circ} \mathrm{O}$ contrato especial de trabalho desportivo deverá conter cláusula expressa reguladora de sua prorrogação automática na ocorrência da hipótese prevista no $\S 7^{\circ}$ deste artigo.

Logo, a suspensão por acidente vinculado à atividade profissional não autoriza a suspensão do contrato de trabalho do atleta. Nesses casos, seriam aplicadas das disposições da previdência 
social, em que o profissional passa a auferir o auxílio doença nos primeiros 15 (quinze) dias de afastamento (a remuneração fica a cargo do clube) e, após, o atleta passaria receber de acordo com o benefício previdenciário.

Seria possível acionar o seguro obrigatório como medida de resguardar esse atleta durante o período de recuperação. Ocorre que, na prática, os médicos do clube é que fazem o acompanhamento do profissional, logo, ele permanece a disposição do clube realizando testes, procedimentos, e outras determinações do clube e do corpo médico, motivo pelo qual acabam recebendo seus salários integralmente. O período de tratamento médico por motivo não vinculado a atividade profissional, contudo, não tem o condão de prorrogar o contrato de trabalho, pois conforme determina o $\S 8^{\circ}$ do artigo 28 , deverá haver previsão expressa nesse sentido.

Até o momento, o presente artigo tratou da configuração geral do Direito Desportivo, apresentando os efeitos e requisitos, modalidades de extinção, e suas peculiaridades, e, finalmente, a suspensão contratual. Doravante, passa-se a análise da responsabilidade civil do empregador pela contaminação por coronavírus do jogador profissional.

\section{RESPONSABILIDADE CIVIL DO EMPREGADOR POR CONTAMINAÇÃO POR CORONAVÍRUS NO CONTRATO ESPECIAL DE TRABALHO DESPORTIVO}

Até aqui, fora possível concluir que as relações que nascem do esporte possuem características diferenciadas com relação ao trabalho regular. O atleta possui deveres e direitos específicos, ao passo que a contratante (empregador) também deverá cumprir às imposições previstas na Lei $n^{\circ}$ 9.615/98. A crise na saúde, em razão da contaminação por Coronavírus é uma situação singular que afetou em especial os espetáculos desportivos. Campeonatos foram interrompidos, estádios foram fechados e tudo se deu em razão do reconhecimento do estado de calamidade pública.

No mundo não foi diferente, a OMS emitiu informações que levaram a FIFA e outras Federações desportivas a suspender diversos campeonatos que estavam em andamento ${ }^{3}$. No caso dos esportes, a contaminação pode se dar em diversos lugares. Na plateia é possível a contaminação, onde o público, em regra, permanece próximo, uns dos outros, seja em razão da euforia da torcida ou por, até então, não ter existido qualquer regulamentação relativa ao distanciamento social.

Os jogadores e envolvidos no espetáculo, por sua vez, também podem ficam expostos. E, portanto, haveria responsabilidade civil do empregador por contaminação por Coronavírus no Contrato Especial de Trabalho Desportivo? O artigo $7^{\circ}$, inciso XXVIII, da Constituição Federal, assegura ao trabalhador o seguro contra acidentes de trabalho, a cargo do empregador, sem excluir a indenização a que este está obrigado, quando incorrer em dolo ou culpa. Os jogadores profissionais, além dessa previsão constitucional, conforme tratado linhas acima, são acobertados por seguro pessoal de vida e de acidentes pessoais. Nesse cenário, de proteção previdenciária e civil, será necessária a análise dos requisitos próprios que desencadeariam a proteção do trabalhador em ambos os sistemas.

\footnotetext{
${ }^{3}$ Mundial de Clubes de 2021, Eurocopa e Copa América, Campeonatos Estaduais e Grandes Ligas Disponível em: $\quad$ https://veja.abril.com.br/esporte/coronavirus-no-esporte-os-principais-eventos-afetados-pela-pandemia/ Acesso em: 19 jul. 2020.
} 
Independentemente de atendidos os requisitos do artigo 20 da Lei n 8.213/1991, com a consequente caracterização da contaminação do trabalhador pelo Coronavírus como doença ocupacional, certo é que, na forma do artigo $7^{\circ}$, XXVIII da Constituição Federal, poderá ocorrer a responsabilização do empregador caso não sejam atendidos os requisitos específicos do sistema de responsabilidade (ato lesivo, o nexo causal, culpa em sentido amplo e o dano).

No âmbito das relações desportivas, como poderia se dar essa prevenção? O empregador, mesmo entregando equipamentos de proteção individual poderia ser responsabilizado em caso de contaminação de jogadores?

O primeiro dos requisitos gerais de responsabilidade civil subjetiva é o ato lesivo ou a conduta do causador do dano. O artigo 186 do Código Civil exige que a atuação humana que viole direito e cause danos a outrem, como modo de atribuição de responsabilidade civil. Deve-se investigar a respeito da antijuridicidade da conduta, bem como as modalidades de negligência, imperícia ou imprudência.

$\mathrm{Na}$ responsabilidade civil por doença ocupacional dificilmente haverá a modalidade da conduta humana dolosa, pois, em regra, nenhum empregador quer intencionalmente que o empregado sofra um infortúnio laboral. No caso da contaminação por Coronavírus, o requisito do ato lesivo será atendido pela comprovação de omissão do empregador em tomar as medidas de proteção, individual e coletiva, dos seus trabalhadores que ficavam suscetíveis ao contágio, principalmente nos casos em que não houve fornecimento de equipamento de proteção individual e coletivo.

O que tem maior ocorrência nas relações de emprego e que de alguma forma causam o efeito doença ocupacional é o descumprimento às normas de proteção da saúde e segurança do trabalho violando o artigo 157 da CLT, em conduta omissiva e antijurídica.

Em 29 de abril de 2020, pelo Plenário do Supremo Tribunal Federal, foram suspensos os efeitos de dois dispositivos da Medida Provisória (MP) 927/2020 (revogada). Por maioria, foram suspensos o artigo 29, que não considerava doença ocupacional os casos de contaminação de trabalhadores pelo Coronavírus, e o artigo 31, que limitava a atuação de auditores fiscais do trabalho à atividade de orientação. A decisão foi proferida no julgamento de medida liminar em sete Ações Diretas de Inconstitucionalidade (ADIs) ajuizadas contra a MP.

Pela tese formada pelo Supremo Tribunal Federal estaria então reconhecida a responsabilidade civil objetiva nos casos de contaminação por Coronavírus no ambiente de trabalho? Segundo a interpretação dada pelo Supremo Tribunal Federal, pode-se afirmar que no caso de demonstração de negligência da empresa, pela não observância das regras de comando sobre segurança do trabalhador, colocando em risco à integridade física dos seus empregados, existirá nexo causal apto a imputar a responsabilidade da empresa pela ocorrência da doença ocupacional.

Dessa feita, a princípio, não caberá responsabilização objetiva uma vez que observados os protocolos de segurança por parte de entidade desportiva. A título exemplificativo, o próprio Governo do Estado de São Paulo, em conjunto com a Federação Paulista de Futebol instituiu no ano de 2020 o 
"Protocolo de Operação de Jogo"4, que é um instrumento de trabalho multidisciplinar, com orientações para prevenção do contágio ao COVID-19.

A CBF, por exemplo, segue empenhada em encontrar as melhores soluções para garantir a saúde da comunidade do futebol frente à Covid-19. Nessa senda, o atendimento por parte do empregador às normas regulamentadoras, a orientação aos trabalhadores sobre riscos inerentes às suas funções (artigo 157 da CLT), a implantação dos programas de PPRA, PCMSO, LTCAT etc., a fiscalização do uso de equipamentos de proteção individual e coletiva, são essenciais para evitar possíveis acusações de contaminação no ambiente laboral.

Caso o jogador, profissional ou amador, venha a ser contaminado pelo Coronavírus, o nexo causal estará provado se o empregado doente demonstrar que contraiu a enfermidade em razão da conduta omissiva do empregador que não the proporcionou ambiente de trabalho seguro. Dessa forma, a conscientização, a entrega e fiscalização do uso de equipamentos de proteção individual e, o cumprimento das determinações emanadas pelos órgãos de saúde são essenciais para que o empregador se proteja de eventual acusação de contágio em razão do trabalho.

A diligência por parte do empregador desportivo deverá ser ainda maior, desde a locomoção dos jogadores em observância ao distanciamento, a hospedagem que deverá atender às determinações estaduais e municipais de prevenção e mesmo os treinos deverão observar o distanciamento e o uso de máscaras. Outro setor que ficará em evidência será o médico que além das fisioterapias, usuais no âmbito dos esportes, em razão do desgaste corporal, também deverá atuar com afinco na realização de testes que demonstrem a aptidão dos jogadores para estarem em campo, afastando aqueles que eventualmente mostrarem-se desgastados ou com baixa imunidade. Em campo os jogadores de futebol só realizam partidas com exame RT-PCR negativo, dessa forma, verifica-se a postura diligente por parte dos clubes de futebol que, em sua maioria, vêm tomando as precauções necessárias para evitar o contágio da doença.

O COVID-19 trouxe um ambiente de muita incerteza para a medicina e para todos os ramos do saber de forma geral, de modo que mesmo a realização de testes não garante que o contaminado não vá ser novamente portador da doença. Nesse contexto, grande é a incerteza quanto à prevenção, cabendo aos atores sociais diligenciarem da melhor forma, mantendo a higiene e evitando o contágio.

Certo é que ficará caracterizado o nexo causal caso o jogador empregado demonstre que contraiu a enfermidade em razão da conduta omissiva do empregador que não the proporcionou ambiente de trabalho seguro, com a entrega dos equipamentos para sua proteção. Por outro lado, há que se considerar que a profissão de jogador, em tese, não expõe o profissional às pessoas infectadas, diferentemente, por exemplo do ramo da saúde.

A culpa é consciente, mas o resultado é involuntário, decorrência da falta de cautela, atenção ou cuidado do agente ofensor, tecnicamente conceituada como a consciente e intencional conduta do agente que pratica um ato que acaba causando dano à vítima. No caso de doença ocupacional, a prova da conduta culposa do empregador é configurada com a violação do artigo 157 da CLT, o qual atribui

\footnotetext{
${ }^{4}$ Disponível em: https://futebolpaulista.com.br/REPOSITORIO/INSTITUCIONAL/ESTATUTO/6372979706590352
} 30.PDF Acesso em: 19 jul. 2020. 
às empresas o dever de cumprir e fazer cumprir as normas de segurança e medicina do trabalho, instruir os empregados, através de ordens de serviço, quanto às precauções a tomar no sentido de evitar acidentes do trabalho ou doenças ocupacionais, adotar as medidas que Ihes sejam determinadas pelo órgão regional competente e facilitar o exercício da fiscalização pela autoridade competente

O dano, finalmente, pode ser conceituado como a lesão ao patrimônio de uma pessoa, a violação do conjunto de bens e direitos de que é titular, a violação a interesses juridicamente protegidos, razão pela qual a referida violação repercute sobre a vítima podendo atingir os seus interesses patrimoniais e extrapatrimoniais.

No âmbito trabalhista, o texto incluído da Consolidação das Leis do Trabalho, por meio da Lei 13.467/2017 estabelece que as reparações de danos de natureza extrapatrimonial decorrentes da relação de trabalho serão disciplinadas, apenas, pelos artigos 223-A a 223-G da CLT. O dispositivo introduz a possibilidade dos trabalhadores de sofrerem danos existenciais em razão de condutas lesivas praticadas pelos empregadores.

Conclui-se pela possibilidade de responsabilização civil do empregador por contágio por Coronavírus, apenas se demonstrada a negligência pelo empregador quanto à conscientização, entrega e fiscalização do uso de equipamentos de proteção individual e coletiva, e, finalmente, a inobservância às normas regulamentares e às diretrizes emanadas pelos municípios e estados. No âmbito das relações desportivas, a prevenção se dará com a conscientização aos jogadores, bem como por meio de higiene, uso de máscaras de proteção e distanciamento, na medida do possível.

Dependendo do contexto fático, o Coronavírus poderá ser considerado doença ocupacional. Portanto o empregador que entregue equipamentos de proteção individual e fiscalize o seu uso poderá afastar essa condição, afastando eventual pedido de responsabilização em caso de contaminação. Na hipótese de comprovação de nexo causal, o dano extrapatrimonial será disciplinado

pelos artigos 223-A a 223-G da CLT, os quais foram incluídos no ordenamento jurídico pela Lei $13.467 / 2017$.

\section{CONCLUSÃO}

Pelo exposto ao longo do estudo, é possível estabelecer-se algumas conclusões.

O contrato de trabalho desportivo, apesar de submetido às regras do direito do trabalho, possui natureza jurídica sui generis, considerando que existem direitos e deveres recíprocos que nem sempre constam expressos na legislação, sendo oriundos da autonomia.

Com relação aos princípios, por certo, aplicam-se os gerais do contrato de trabalho, consubstanciados na onerosidade, habitualidade, subordinação e pessoalidade. Contudo, a Lei $n^{\circ}$ 9.615/98 elenca tanto outros princípios que regem a relação, de modo que é necessária verdadeira ponderação de valores para se estabelecer os reais contornos dessa modalidade contratual.

Por sua vez, a Lei nº 9.615/98 resolveu diversas controvérsias dessa relação, ao expor um conteúdo mínimo de direitos e deveres para os atletas e as entidades desportivas. Regrou, ainda, o contrato de trabalho, maculando com o vício da nulidade várias cláusulas de usualmente eram positivadas nos contratos em prejuízo do atleta que, normalmente, não possui conhecimento bastante 
para evitá-las. Quanto à multa indenizatória e compensatória, a Lei n 12.395/2011, promoveu alterações na Lei $n^{\circ}$ 9.615/98, teve o mérito de regulamentá-la tanto com relação ao valores mínimos, bem como em relação à responsabilidade pelo pagamento. Trata-se de evidente vantagem do ordenamento jurídico brasileiro, como forma de prevenção de litígios.

Com a situação imposta pela COVID-19, reflexos foram sofridos, também no âmbito desportivo. Dessa feita, o presente estudo pretendeu, além da análise do contrato desportivo, avaliar as implicações da contaminação por coronavírus e responsabilidade civil atribuível ao empregador do jogador empregado. Foram abordadas as medidas preventivas que devem ser adotadas, bem como foram estabelecidos possíveis critérios para a configuração do nexo causal e da culpa em face do empregador, resultando em dano para o jogador.

Por fim, diante do dano extrapatrimonial verificado, estabeleceu-se a possibilidade de aplicação do quanto disposto nos artigos 223-A a 223-G, da CLT, incluídos a Consolidação das Leis do Trabalho pela Lei $n^{\circ} 13.467 / 2017$.

\section{REFERÊNCIAS}

BRASIL. Lei $n^{\circ} 9.615$ de 24 de março de 1988. Institui normas gerais sobre desporto e dá outras providências. Disponível em: http://www.planalto.gov.br/ccivil_03/leis//9615consol.htm. Acesso em: 19 jul. 2020.

DINIZ, Maria Helena. Tratado teórico e prático dos contratos. 7. ed. São Paulo: Saraiva, 2013, v. 5.

LYRA FILHO, João. Introdução ao direito desportivo. Rio de Janeiro: Irmão Pongetti, 1952.

MARANHÃO, Ney, Mio ambiente laboral futebolístico e responsabilidade civil. In: BELMONTE, Alexandre Agra; MELLO, Luiz Philippe Vieira de; BASTOS, Guilherme Augusto Caputo (Orgs.). Direito do trabalho desportivo. Os aspectos da Lei Pelé frente às alterações da Lei n 12.395/2011. São Paulo: LTr, 2013.

MARTINS, Sergio Pinto. Direitos trabalhistas do atleta profissional de futebol. São Paulo: Atlas, 2011.

MEIRIM, José Manuel. Temas de direito do desporto. Coimbra: Coimbra Editora, 2006.

MOLINA, André Araújo. Acidente ambiental e a responsabilidade civil objetiva agravada do empregador. Revista Sínteses Trabalhista e Previdenciária, São Paulo, ano XXIX, n. 355, p. 64-87, jan. 2019.

MONTAL, Zélia Maria Cardoso; CARVALHO; Luciana Paula de Vaz (Org.). Reforma trabalhista em perspectiva: desafios e possibilidade. 2. ed. São Paulo: LTr, 2019.

VEIGA, Mauricio de Figueiredo Corrêa da. Manual de direito do trabalho desportivo: atualizado com a Lei n 13.467/2017 e com a Lei n 54/2017, de Portugal. 3. ed. São Paulo: LTr, 2020.

Recebido: 21.07 .2020

Aprovado: 01.03.2021

Como citar: MATEO, Priscilla Pereira; MANUS, Pedro Paulo Teixeira. O contrato de trabalho desportivo e a responsabilidade civil do empregador pela contaminação por coronavírus no contrato especial de trabalho desportivo. Revista IBERC, Belo Horizonte, v. 4, n. 2, p. 67-78, maio/ago. 2021. 